Bodnar A. I.

\title{
PECULIARITIES OF CHANGES IN BIOIMPEDANCE INDICES IN WOMEN AGED 18-21 DURING A LONG-TERM DANCE AND POWER TRAINING
}

\author{
Petro Mohyla Black Sea National University, Mykolaiv, Ukraine
}

Spenileo@gmail.com

The article presents the research results determining the impact of dance and power training on the dynamics of bioimpedansometry (body composition) indices in women aged 18-21 years during 3 months.

At the beginning of the study, participants were divided into two groups: control group members used mainly dance fitness elements during the training; experimental group participants used programs of power fitness training, comprising mainly exercises on simulators.

The dynamics of the studied parameters were monitored using the non-invasive bioimpedance method. In the course of the research it was found out that the parameters of body composition of the surveyed contingent, fixed during each month of training showed a more pronounced tendency to change among the representatives of the control group. Thus, the indices of fat body mass in the control group decreased during 3 months of training in dance fitness by almost $8.0 \%(p<0.05)$ compared to the basal data.

At the same time, the experimental group representatives decreased the index by only 4.9\% $(p<0.05)$ for the same period of time This fact allows us to assume that it is dance fitness physical activities that contribute to significant energy expenditure in the body of women at this age and lead to similar changes in body fat level.

At the same time, the indices of active body mass showed an increase during 3 months of training, both in the control group representatives and the experimental group participants by $1.2 \%$ and $1.6 \%$, respectively, compared with the basal data, which indicates positive processes of their adaptation.

However, despite the significant external dynamics of the most controlled body composition indices in the examined contingent revealed during the research, especially during dance fitness, there is a question of determining which body reactions (adaptation or compensatory) have stimulated these changes in women of this age and which processes will be going on after using these types of muscular activity further.
Keywords: dance and power fitness, physical load, women aged 18-21 years, bioimpedansometry, adaptation changes.

Research relation to the plans, programs and department themes. The article is a fragment of the planned scientific work "Development and implementation of innovative technologies and correction of the functional state of a human in conditions of physical load in sports and rehabilitation", (State registration number 0117U007145).

Introduction. The modern system of fitness industry, despite the great diversity of existing species and classifications in the world, mainly consists of two main areas: wellness and professional $[3,7,8]$. One of the widespread variants of the wellness direction is using elements of dance and power fitness [1, 4, 9]. Each of these areas is quite different from the other not only in the structure of training, its volume and intensity, but also in the techniques of performing specialized exercises, etc. The main difference is in the effectiveness of solving certain tasks, taking into account the level of physical fitness of a person, his/her gender and age characteristics [2, 5].

The problem of finding effective mechanisms for increasing the level of the body functional state of young women by using various forms of physical activity was addressed to not only by specialists in physical education $[5,11]$, but also by scientists in the fields of medicine and biology $[8,12,13]$.

Researchers [5,9] paid considerable attention to the study of peculiarities of influence of different in structure and orientation fitness training on the body of student youth, using this form of physical activity as an additional means during physical education classes. A number of works researched the influence of certain types of fitness (Pilates, aquafitness) on the body of mature women [3].

However, in most cases, researchers determined the effectiveness of the impact of the proposed models of muscular activity on the organism of the surveyed contingent taking into account only the peculiarities of 
the anthropometry indices dynamics and features of the cardiovascular system parameters [4, 5, 12]. At the same time, there were no studies on the nature of changes in the level of bioimpedansometry indices in women aged 18-21 years, especially in the conditions of long-term using opposite in structure types of fitness training, involving sufficiently different systems of energy supply, mechanisms of control and correction of intensity and volume of loads [7, 8, 10, 12].

The purpose of this study was to determine the peculiarities of the dynamics of body composition in women aged 18-21 years using training programs in dance and power fitness.

Material and methods. 50 practically healthy women from 18 to 21 , who were not previously systematically engaged in power and dance fitness, were surveyed. Considering the purpose and objectives of the study, we formed two research groups from this contingent: the control and experimental.

The control group representatives used universally recognized dance fitness training program [4] during 3 months of training. At the same time, the experimental group participants used the wide spread training program in power fitness for this age constructed by the leading experts in the field of muscular activity [6, 7] (Table 1). The trainings were held three times a week.

All participants who took part in the studies had previously undergone a medical examination and comprehensive biochemical laboratory control (16 indices). The results of medical examination showed that they had no medical contraindications for participation in the studies.

The dynamics of the studied indices of bioimpedansometry (indices of body composition) were measured at the beginning of the study and during three months of systematic fitness training with a control interval of one month. To evaluate the above indices we used bioimpedance analyzer, a diagnostic computer-hardware-software-complex KM-AP-01 produced by "Diamond- AST" (body composition analyzer) (VYUSK. 941118.001 PE) [1].

Statistical analysis of the study results was performed using the IBM *SPSS ${ }^{*}$ Statistics 22 package. The arithmetic mean and the error of the mean were determined. To check the validity of the difference we used non-parametric criteria (Wilcoxon test).

Results and discussion. In the course of studying the peculiarities of the dynamics of the body composition indices of the control and experimental groups participants in the given conditions of muscular activity, we noticed certain tendencies to change of the controlled indices of bioimpedansometry, which are graphically presented in Fig. 1-4.

Figure 1 presents the results of changes in the index of fat body mass (FBM,\%) in females of the examined groups during 3 months of the study in different conditions of physical activity. It was found out that, despite the virtually identical anthropometric parameters of the representatives of both groups, the initial values of the body fat index of the control group participants were $3.0 \%$ higher than those of their opponents.

The analysis of the results showed that after the first month of training the body fat index decreased by $1.7 \%(p<0.05)$ in the control group compared to the basal data. However, women of the experimental group did not show such changes. On the other hand, after the second month of training, we detected a $0.7 \%$ decrease in the experimental group who used a power training program. We did not observe changes in the control group representatives who took up

Table 1 - Power and dance fitness programs used by the experimental group participants

\begin{tabular}{|c|c|c|}
\hline $\begin{array}{c}\text { Structural } \\
\text { components }\end{array}$ & Power Fitness Training Program & Dance Fitness Training Program \\
\hline $\begin{array}{l}\text { A complex } \\
\text { of means }\end{array}$ & $\begin{array}{l}\text { A set of basic and isolation exercises on simulators; } \\
\text { exercise technique meets standard requirements in } \\
\text { power fitness; no more than } 2-3 \text { muscle groups are } \\
\text { involved in performing basic exercises }\end{array}$ & $\begin{array}{l}\text { A set of } 20-25 \text { exercises (basic steps) that are } \\
\text { performed sequentially without stopping with a } \\
\text { partial or full change of kinematic, dynamic and } \\
\text { rhythmic characteristics of their elements }\end{array}$ \\
\hline $\begin{array}{l}\text { Load } \\
\text { parameters }\end{array}$ & $\begin{array}{l}\text { The total duration of the training is about } 75-90 \text { min- } \\
\text { utes; the working weight of the load is } 35-50 \% \text { of } 1 \\
\text { maximum exercise fullfilment; the duration of the set } \\
\text { is about } 90 \mathrm{~s} \text {; rest between sets varies within } 60 \mathrm{~s} \text {; } \\
\text { exercises are performed with full amplitude; } 3-4 \\
\text { sets per one exercise; } 28-30 \text { repetitions in a set; no } \\
\text { more than } 7-8 \text { exercises during one training }\end{array}$ & $\begin{array}{l}\text { The total duration of the training is } 60 \text { minutes; } \\
\text { each combination is made up of } 32 \text { rhythm counts } \\
\text { and consists of } 4 \text { elements with } 8 \text { repetitions for } \\
\text { each; the duration of one repetition is } 3-4 \text { seconds }\end{array}$ \\
\hline $\begin{array}{l}\text { Correction } \\
\text { mechanism }\end{array}$ & $\begin{array}{l}\text { The quantity of the projectile working mass changes } \\
\text { (it is increased or decreased by } 10-15 \%) \text {, the se- } \\
\text { quence and variability of using training exercises } \\
\text { also change. Exercise speed and amplitude are } \\
\text { rarely changed }\end{array}$ & $\begin{array}{l}\text { The technique of performing exercises changes } \\
\text { due to the amplitude and position of the body in } \\
\text { space; change in intensity due to the rhythm of } \\
\text { performance; the level of performing exercise in- } \\
\text { creases and exercise variability constantly } \\
\text { changes, too }\end{array}$ \\
\hline
\end{tabular}




\section{Фізичне виховання і спорт}

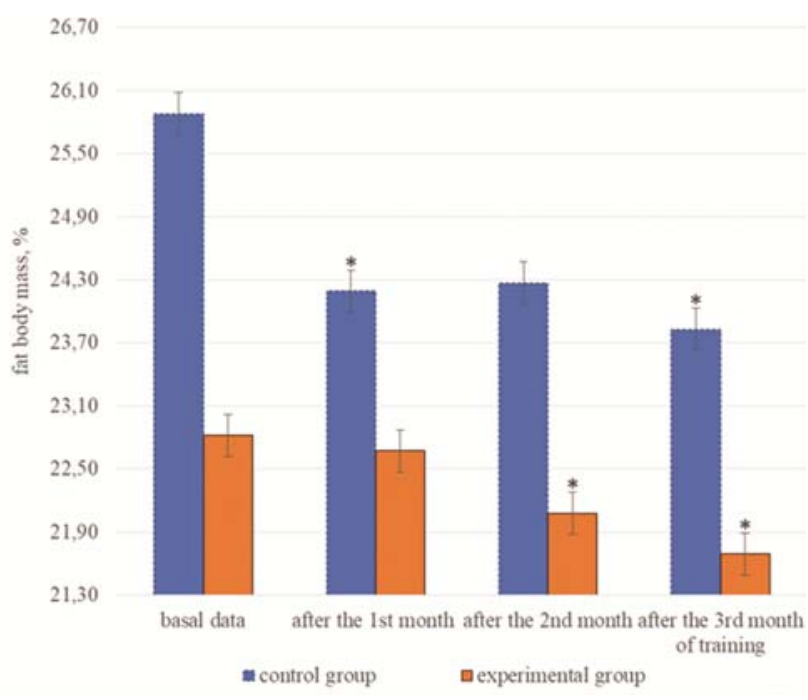

Fig. 1. Dynamics of the fat body mass indices (FBM, \%) in participants of both groups during all stages of the study, $\mathrm{n}=50$

dance fitness training program. After the third month of research, there was a slight decrease in the control index in participants of both groups.

Thus, the obtained results indicated that, despite the significant difference between the training programs used by the participants of the surveyed groups during 3 months of training, the body fat mass index showed a more pronounced tendency (almost 2 times) to decrease in the control group representatives who used dance fitness program in muscular activity.

Figure 2 presents the results of changing the parameters of fat-free body mass (FFBM, $\mathrm{kg}$ ) (the part of body weight that includes everything that is not fat: muscles, all internal organs, bones, nerve cells, all fluids that are in the body $[1,3])$ in the participants of

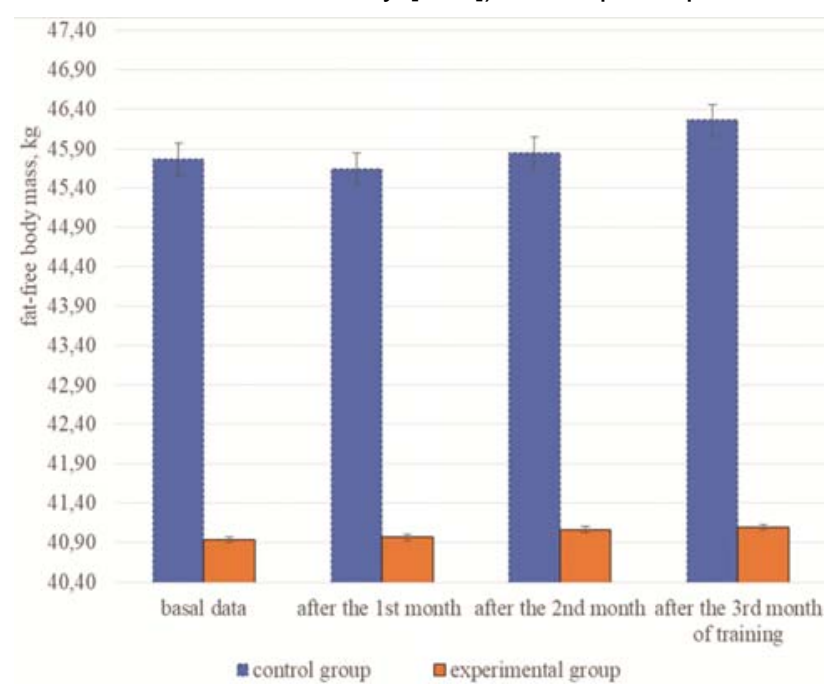

Fig. 2. Dynamics of the fat-free body mass indices (FFBM, \%) in participants of both groups during all stages of the study, $n=50$ the study. Despite virtually identical anthropometric parameters of the representatives of both surveyed groups, we detected a significant discrepancy between the controlled indices among the participants at the beginning of the experiment. Thus, the index of fat -free body mass fixed in the control group was by $10.6 \%(p<0.05)$ higher than in the experimental group representatives.

At the same time, the analysis of the research results showed that the fat-free body mass index practically did not change in the control group (dance fitness program) and the experimental group (power fitness program) representatives during three months of the studies.

Figure 3 presents the results of controlling the dynamics of the active body mass index (ABM,\%) of the surveyed contingent during 3 months of study.

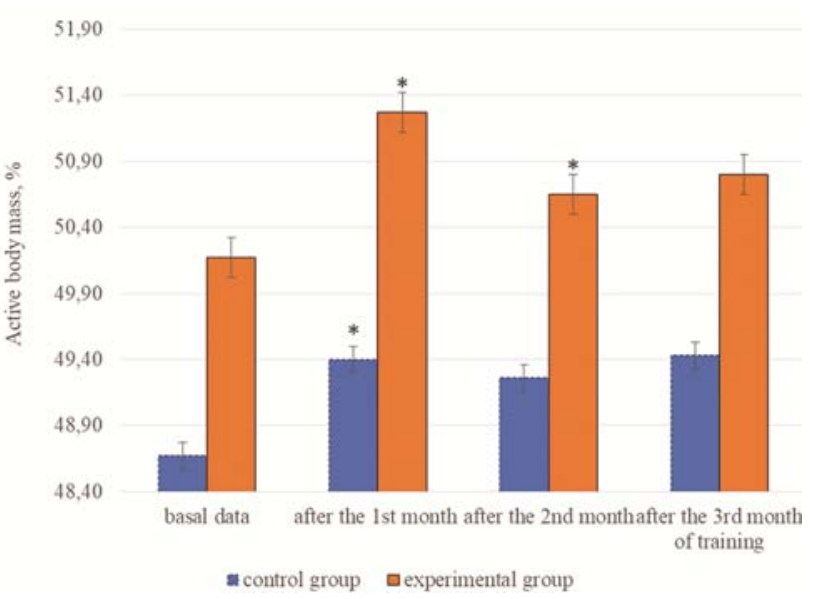

Fig. 3. Dynamics of the active body mass indices (ABM, \%) in participants of both groups during all stages of the study, $\mathrm{n}=50$

Analysis of the study results indicated that the basal level of active cell body mass in the representatives of both groups, fixed at the beginning of the experiment, had a difference (1.7\%), despite almost identical anthropometric parameters.

Analysis of the obtained results showed that after the $1^{\text {st }}$ month of training, the ABM increased both in the control and experimental groups compared to the basal data. After the $2^{\text {nd }}$ month of training, we traced a decrease by $0.6 \%$ in the control group, who used the dance fitness training program. Among the representatives of the experimental group, no corresponding changes were observed in the conditions of power training. After the $3^{\text {rd }}$ month of research, we saw a slight increase in the control index in participants of both groups.

\section{Conclusions}

1. The research proved that the fat body mass indices decreased in the control group during 3 months of dancing fitness by almost $8.0 \%(p<0.05)$ compared 
to the basal data. At the same time, the experimental group representatives decreased the same index by only $4.9 \%(p<0.05)$ during the same period of time. This fact allows us to assume that it is the dance fitness physical activities that contribute to considerable energy expenditure in the body of women of this age and lead to similar changes in fat body mass levels.

2. The studied indices of the body composition in the surveyed contingent showed different direction dynamics depending on the peculiarities of the training process and parameters of the volume and intensity of power loads. Indices of bioimpedansometry can be used as informative criteria for assessing adaptive changes in the body of women in the process of systematic fitness, regardless of its varieties.

Prospects for further research. Modern situation requires using more informative comprehensive methods of diagnosis for identification of adaptive changes in the body of people of different ages and sex in the conditions of intensive muscular activity of different nature and orientation. The use of complex biochemical methods for the diagnosis of adaptive changes in the body of adolescents in the study of the impact of anaerobic loads will allow establishing the effectiveness of a particular model of muscle activity more clearly and will require additional complex studies.

However, despite the significant external dynamics of the most controlled body composition indices in the examined contingent revealed during the research, especially during dance fitness, there is a question of determining which body reactions (adaptation or compensatory) have stimulated these changes in women of this age and which processes will be going on after using these types of muscular activity further.

\section{References}

1. Kompleks KM-AR-01 komplektatsiya «Diamant - AST» (analizator sostava tela): instruktsiya operatora [KM-AP-01 Complex "Diamond-AST" complete set (body composition analyzer): operator's manual]. SPb: Izd-vo Tsentr «Diamant»; 2007. 18 c. [Russian]

2. Kudrya ON, Belova LE, Kapilevich LV. Adaptatsiya serdechno-sosudistoy sistemy sportsmenov k nagruzkam raznoy napravlennosti [Adaptation of cardiovascular system of athletes to loads of different orientation]. Vestnik TGU. 2012; 3 (356): 162-6. [Russian]

3. Martirosov EG, Nikolaev DV, Rudnev SG. Tekhnologii i metody opredeleniya sostava tela [Technologies and methods for determining body composition]. M: Nauka; 2006. 248 p. [Russian]

4. Meerson FZ, Pshennykova MH. Adaptatsyya $k$ stressornym y fyzycheskym nahruzkam [Adaptation to stress and physical activity]. M: Medytsyna]. M: Medytsyna; 1988. s. 19-35. [Russian]

5. Nasledov AD. IBM SPSS Statistics 20 y AMOS: professyonalnyi statystycheskyi analyz dannykh [Statistics 20 and AMOS: professional statistical analysis of data]. SPb: Piter; 2013. 416 p. [Russian]

6. Platonov VN. Srochnaya y dolhovremennaya adaptatsyya sportsmenov $v$ protsesse trenyrovky. Adaptatsyya sportsmenov $k$ trenyrovochnoy nahruzke [Urgent and long-term adaptation of athletes in the training process. Adaptation of athletes to the training load]. Kyev: KHYFK; 1984. p. 10-29. [Russian]

7. Platonov VN. Systema pidhotovky sportsmenov $v$ olympyiskom sporte. Obshchaya teoryya y ee praktycheskye prylozhenyya [The system of training athletes in Olympic sports. General theory and its practical applications]. K: Olympyiskaya literatura; 2004. 808 p. [Ukrainian]

8. Chernozub AA, Titova HV, Dubachynskyi OV, Slavityak OS. Adaptatsiyni zminy v orhanizmi zhinok serednoho viku v umovakh zanyat sylovym fitnesom [Adaptive changes in the body of middle-aged women in the conditions of exercise fatness]. Visnyk Chernihivskoho natsionalnoho pedahohichnoho universytetu. Seriya: Pedahohichni nauky. Fizychne vykhovannya ta sport. 2017; 147(1): 233-8. [Ukrainian]

9. Chernozub AA. Bezpechni ta krytychni rivni fizychnykh navantazhen dlya trenovanykh ta netrenovanykh osib $v$ umovakh m'yazovoi diyalnosti sylovoi spryamovanosti [Safe and Critical Exercise Levels for Trained and Non-Trained Individuals in Muscular Strength Activity]. Fiziolohichnyi zhurnal. 2016; 62(2): 110-7. [Ukrainian] doi: 10.15407/ fz62.02.110

10. Goto K, Ishii N, Kizuka T, Kraemer RR. Hormonal and metabolic responses to slow movement resistance exercise with different durations of concentrican deccentricactions. Eur J Appl Physiol. 2009; 106(5): 731-9. doi: 10.1007/ s00421-009-1075-9

11. Kraemer RR, Castracane VD. Endocrine alterations from concentric vs. eccentric muscle actions: a brief review. Metabolism. 2015; 64(2); 190-201. PMID: 25467839. DOI: 10.1016/j.metabol.2014.10.024

12. Martín-Hernández J, Marín PJ, Menéndez H, Ferrero C, Loenneke JP, Herrero AJ. Muscular adaptations after two different volumes of blood flow-restricted training. Scand J Med Sci Sports. 2013; 23(2): 114-20. PMID: 23278841. DOI: $10.1111 / \mathrm{sms} .12036$

13. Philippe AG, Py G, Favier FB, Sanchez AM, Bonnieu A, Busso T, et al. Modeling the responses to resistance training in ananimal experiment study. Biomed Res Int. 2015; 2015: 914-60. doi: 10.1155/2015/914860 
14. Plews DJ, Laursen PB, Stanley J, Kilding AE, Buchheit M. Training adaptation and heart rate variability in elite endurance athletes: opening the door to effective monitoring. Sports Med. 2013; 43(9): 773-81. PMID: 23852425. DOI: 10.1007/s40279-013-0071-8

15. Seynnes OR, Kamandulis S, Kairaitis R, Helland C, Campbell EL, Brazaitis M, et al. Effect of androgenic-anabolic steroids and heavy strength training on patellartendon morphological and mechanical properties. Journal of Applied Physiology. 2013; 115(1): 84-9. PMID: 23620489. DOI: 10.1152/japplphysiol.01417.2012

16. Titova HV. Changing the body composition parameters in women of both periods of the mature age engaged in power fitness. Ukrainian journal of medicine, biology and sport. 2018; 6(15): 323-7. doi: 10.26693/jmbs03.06.323

\section{УдК 796.412 \\ ОСОБЛИВОСТІ ЗМІНИ ПОКАЗНИКІВ БІОІМПЕДАНСОМЕТРІЇ У ЖІНОК 18-21 РОКІВ ПІД ЧАС ДОВГОТРИВАЛИХ ЗАНЯТЬ ТАНЦЮВАЛЬНИМ ТА СИЛОВИМ ФІТНЕСОМ \\ Боднар А. I.}

Резюме. В статті представлено результати дослідження щодо визначення впливу занять танцювальним та силовим фрітнесом на динаміку показників біоімпедансометрії (складу тіла) жінок 18-21 років протягом 3 місяців.

На початку досліджень, учасники були поділені на дві групи: представники контрольної групи під час тренувань застосовували переважно елементи танцювального фрітнесу; особи експериментальної групи застосовували програми тренувальних занять з силового фітнесу в основі якої переважно застосовувались вправи на тренажерах.

Динаміку досліджуваних показників контролювали за допомогою неінвазійного методу біоімпедансометрії. В процесі досліджень було встановлено, що параметри складу тіла обстеженого контингенту, фіксовані протягом кожного місяцю занять демонструють більш виражене тенденцію до змін саме серед представників контрольної групи. Так, саме у осіб контрольної групи показники жирової маси тіла зменшились протягом 3 місяців занять танцювальним фітнесом майже на 8,0\% $(p<0,05)$ порівняно з вихідними даними. При цьому, за аналогічний проміжок часу, у представників експериментальної групи досліджуваний показник зменшився лише на 4,9\% (p<0,05). Даний фракт дозволяє припустити, що саме фрізичні навантаження, які використовуються під час занять танцювальним фітнесом сприяють значним енергозатратам в організмі жінок даного віку та призводять до подібних змін рівня жирової маси тіла.

В той же час, показники активної маси тіла демонструють зростання протягом 3 місяців досліджень як серед представників контрольної групи на 1,2\% та і учасників експериментальної на 1,6\% порівняно 3 вихідними даними, що свідчить про позитивні процеси адаптації.

Однак, незважаючи на виявлену в процесі досліджень суттєву зовнішню позитивну динаміку більшості контрольованих показників складу тіла обстеженого контингенту, особливо саме під час занять танцювальним фітнесом, відкритим залишається питання щодо визначення за рахунок адаптаційних чи компенсаторних реакцій в організмі жінок даного віку відбулися відповідні зміни, та які процеси будемо спостерігати при подальшому використанні даних різновидів м'язової діяльності.

Ключові слова: танцювальний та силовий фітнес, фрізичні навантаження, жінки 18-21 років, біоімпедансометрія, адаптаційні зміни.

\section{УдК 796.412 \\ ОСОБЕННОСТИ ИЗМЕНЕНИЯ ПОКАЗАТЕЛЕЙ БИОИМПЕДАНСОМЕТРИИ \\ У ЖЕНЩИН 18-21 ЛЕТ ПРИ ДЛИТЕЛЬНЫХ ЗАНЯТИЯХ ТАНЦЕВАЛЬНЫМ И СИЛОВЫМ ФИТНЕСОМ \\ Боднар А. И.}

Резюме. В статье представлены результаты исследования по определению влияния занятий танцевальным и силовым фитнесом на динамику показателей биоимпедансометрии (состава тела) женщин 18-21 лет в течение 3 месяцев.

В начале исследований, участники были разделены на две группы: представители контрольной группы во время тренировок применяли преимущественно элементы танцевального фитнеса; лица экспериментальной группы - применяли программу тренировочных занятий по силовому фитнесу в основе которой преимущественно применялись упражнения на тренажерах.

Динамику исследуемых показателей контролировали с помощью неинвазивного метода биоимпедансометрии. В процессе исследований было установлено, что параметры состава тела обследованного контингента, фриксированные в течение каждого месяца занятий, демонстрируют более выраженное 
тенденцию к изменениям именно среди представителей контрольной группы. Да, именно у лиц контрольной группы показатели жировой массы тела уменьшились в течение 3 месяцев занятий танцевальным фитнесом почти на 8,0\% ( $<<0,05)$ по сравнению с исходными данными. При этом, за аналогичный промежуток времени, у представителей экспериментальной группы исследуемый показатель уменьшился лишь на 4,9\% ( $p<0,05)$. Данный фрак позволяет нам предположить, что именно фризические нагрузки, которые используются во время занятий танцевальным фитнесом способствуют значительным энергозатрат в организме женщин данного возраста и приводят к подобным изменениям уровня жировой массы тела.

В то же время, показатели активной массы тела демонстрируют рост в течение 3 месяцев исследований как среди представителей контрольной группы на 1,2\% и участников экспериментальной на 1,6\% по сравнению с исходными данными, что свидетельствует о позитивных процессах адаптации.

Однако, несмотря на обнаруженную в процессе исследований существенную внешнюю положительную динамику большинства контролируемых показателей состава тела обследованного контингента, особенно именно во время занятий танцевальным фитнесом, открытым остается вопрос об определении за счет адаптационных или компенсаторных реакций в организме женщин данного возраста состоялись соответствующие изменения, и которые процессы будем наблюдать при дальнейшем использовании данных разновидностей мышечной деятельности.

Ключевые слова: танцевальный и силовой фитнес, фризические нагрузки, женщины 18-21 лет, биоимпедансометрия, адаптационные изменения.

The authors of this study confirm that the research and publication of the results were not associated with any conflicts regarding commercial or financial relations, relations with organizations and/or individuals who may have been related to the study, and interrelations of coauthors of the article. 